\title{
AMS RADIOCARBON DATING OF PALEOLITHIC-AGED CHARCOAL FROM EUROPE AND THE MEDITERRANEAN RIM USING ABOX-SC
}

\author{
F Brock • T F G Higham \\ Oxford Radiocarbon Accelerator Unit, Research Laboratory for Archaeology \& the History of Art, University of Oxford, \\ Dyson Perrins Building, South Parks Road, Oxford, OX1 3QY, United Kingdom. Email: fiona.brock@ rlaha.ox.ac.uk.
}

\begin{abstract}
Radiocarbon dating of charcoal > 25-30 kyr can be problematic due to contamination from exogeneous carbon and the variable effectiveness of ${ }^{14} \mathrm{C}$ pretreatments to remove it. Bird et al. (1999) developed the ABOx-SC (acid-base-oxidation-stepped combustion) method for removing contaminants from older charcoal samples, which involves a harsher treatment than traditional acid-base-acid (ABA) pretreatments. This method has been shown to considerably improve the reliability of dating old charcoal from sites in Australia, South Africa, Brazil, and Malaysia (Bird et al. 1999, 2003; Turney et al. 2001; Santos et al. 2003; Higham et al. 2009a). Here, we apply the technique to material from 5 Paleolithic sites from Europe and the Mediterranean Rim. For 2 of the sites (Kebara Cave, Israel and Taramsa Hill, Egypt), the ABOx-SC and ABA methods produced similar dates. However, in the case of 1 site, the Grotta di Fumane in Italy, ABOx-SC pretreatment produced significantly older results from those of ABA methods, requiring substantial reinterpretation of the archaeological sequence of the site. The rigorous nature of the technique resulted in a high failure rate for sample pretreatment, and insufficient material survived the pretreatment for dating from Grotte des Pigeons, Morocco or Gorham's Cave, Gibraltar.
\end{abstract}

\section{INTRODUCTION}

Charcoal from archaeological and environmental contexts is generally thought to be a reliable material for radiocarbon dating, as long as the stratigraphic and contextual integrity of the samples are maintained. Most ${ }^{14} \mathrm{C}$ labs traditionally use an acid-base-acid or ABA pretreatment for charcoals (also known as acid-alkali-acid or AAA) prior to dating. Such a technique uses acids and bases to remove carbonates and humic/organic acid contaminants, respectively, and is thought to be sufficient to remove most contaminants from charcoals for dating. However, ${ }^{14} \mathrm{C}$ dating of material $>\sim 25-30 \mathrm{kyr}$ BP can be problematic. Once laboratory background is established to an acceptably low and reproducible level, contamination by exogeneous carbon and the extent to which it has become chemically associated or cross-linked to the original material, plus the effectiveness of ${ }^{14} \mathrm{C}$ pretreatments to remove such contamination, is the principal challenge to accuracy. A small amount of contamination can result in significant errors: one often quoted example is of a ${ }^{14} \mathrm{C}$-"dead" sample with just $1 \%$ modern contamination, which would yield a date of $\sim 37 \mathrm{kyr}$ (Chappell et al. 1996).

Recently, Bird et al. (1999) developed a method for dating older charcoals by using a more rigorous treatment compared with the traditional ABA approach. This ABOx-SC (acid-base-oxidationstepped combustion) method incorporates a wet oxidation step after the initial acid and base washes, followed by a series of stepped combustions prior to dating. Applying this method to samples from Australia, South Africa, and Brazil, Bird et al. (1999, 2003), Turney et al. (2001), and Santos et al. (2003) produced results that were often much older than previously established chronologies determined on the same material from the same archaeological contexts, and showed the total methodological blank of the ABOx-SC method to be $0.1 \pm 0.02 \mathrm{pMC}$ (giving a background age of $\sim 55 \mathrm{kyr} \mathrm{BP})$.

At the Oxford Radiocarbon Accelerator Laboratory (ORAU), we have applied an ABOx-SC technique based on that of Bird et al. (1999) to charcoal samples from several Paleolithic sites. Comparison of these dates with those measured on the same material following ABA pretreatments resulted in little or no difference for samples from Chauvet Cave, France (Cuzange et al. 2007) and KremsHundssteig, Austria (Wild et al. 2008), but significantly older ABOx-SC dates from Niah Cave, Malaysia (Higham et al. 2009a). In this study, we apply the method to charcoal from 5 Paleolithic

C 2009 by the Arizona Board of Regents on behalf of the University of Arizona

Proceedings of the 5th International ${ }^{14} \mathrm{C}$ and Archaeology Symposium, edited by Irka Hajdas et al.

RADIOCARBON, Vol 51, Nr 2, 2009, p 839-846 
sites from Europe and the Mediterranean Rim. With the exception of 1 site (Grotte des Pigeons, Morocco), all of the samples had previously been dated at ORAU, and were chosen to represent sites of specific interest in terms of Paleolithic archaeology. Grotte des Pigeons and Gorham's Cave were of particular interest because ${ }^{14} \mathrm{C}$ dates from these sites have not always agreed with dates achieved by other dating techniques from the same sequences.

\section{ARCHAEOLOGICAL SITES}

A total of 21 charcoal samples were chosen for (re-)dating (Figure 1). The Grotta di Fumane (8 samples) is a key site in the Veneto region of northern Italy. It has a long Mousterian and Aurignacian sequence (largely dated using charcoal) covering a range of several millennia (about 34-46 kyr BP) and documents a very important presence of a distinctive proto-Aurignacian (termed "Fumanian" by some) industry in southern Europe (see Broglio and Gurioli 2004; Broglio et al. 2006; Mellars 2006).

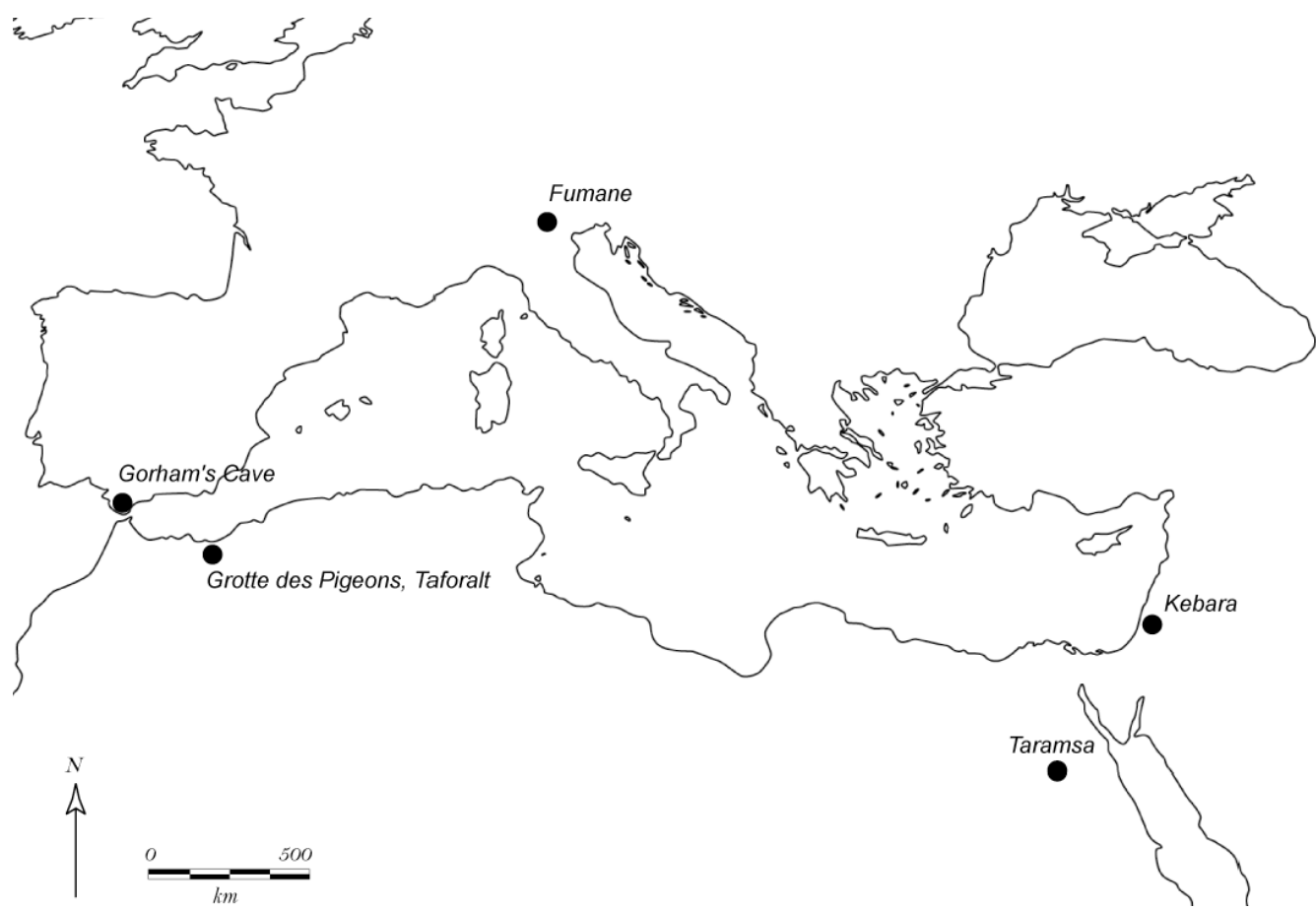

Figure 1 Map of Paleolithic sites from Europe and Mediterranean Rim from which samples were dated for this study

Kebara Cave ( 3 samples) is a limestone cave on the western escarpment of the Mount Carmel range, northeast of Caesaria in Israel. It contains a key sequence of Middle to Upper Paleolithic cultural levels, including Mousterian, Ahmarian, and Levantine Aurignacian horizons (Bar-Yosef et al. 1992, 1996).

Taramsa Hill in Egypt (4 samples) is a site that has yielded evidence of Early, Middle, and Late Paleolithic chert extraction activity. The burial of an anatomically modern human child has made the site one of the few in Africa that has yielded evidence of Late Pleistocene human remains (Vermeersch et al. 1998). The burial is thought to date to $49,800-80,400 \mathrm{BP}$. 
Gorham's Cave (4 samples) is one of the Gibraltar complex of caves that demonstrates a late Middle Paleolithic sequence. The archaeological and chronometric data obtained implies strongly a very late survival of Neanderthals in southern Iberia, possibly as late as 24,000-28,000 BP (Finlayson et al. 2007: but see Zilhão and Pettitt 2007). A large series of samples from Gorham's have previously been dated (Pettitt and Bailey 2000) and further dates of marine shell, as well as a review of the chronology of the site is shortly to be published (Higham et al. 2009c).

The Grotte des Pigeons is located in northeast Morocco ( 2 samples) near the village of Taforalt in the Beni Snassen Mountains, approximately $40 \mathrm{~km}$ inland from the modern Mediterranean coast. It documents an important sequence spanning the Middle to Upper Paleolithic of northwest Africa, in particular regarding the question of the presence and antiquity of the Iberomerusian, the earliest known Upper Paleolithic industry of the Mahgreb (Barton et al. 2007). ${ }^{14} \mathrm{C}$, OSL, TL, and U-series dates from the cave span the Middle and Upper Paleolithic and are being used alongside paleoenvironmental reconstructions to determine whether archaeological and environmental changes may be correlated with global or regional climatic events.

\section{METHODS}

With the exception of the samples from the Grotte des Pigeons, all of the samples had previously been dated at ORAU using the ABA pretreatment method. In this study, all samples were prepared for dating using ABOx-SC pretreatment. Only those from Grotte des Pigeons and those with OxA numbers $<10,000$ were subjected to the ABA pretreatment. This was undertaken to enable more relevant comparison between $\mathrm{ABOx}$ and $\mathrm{ABA}$ determinations.

Charcoal samples were roughly crushed before undergoing sequential ABA and ABOx-SC wet chemistry procedures as listed in Table 1 . For both procedures, the initial acid wash removes carbonate contaminants. The subsequent base wash is then applied to remove humic and other organic acid contaminants, which may be present either from degradation of the sample itself or which have leached into the sample from the burial environment. The base extraction step was repeated one or more times if much humic matter was present until the solution remained clear of humics. In the ABA treatment, the final acid step is used to remove any modern atmospheric $\mathrm{CO}_{2}$, which may have been absorbed by the sample during the base wash. In the ABOx-SC pretreatment, the samples then undergo a wet oxidation step with acidified potassium dichromate to remove organic carbon and leave only oxidation-resistant elemental carbon, or OREC (Bird and Gröcke 1997). Bird et al. (1999) generally subjected their samples to the oxidation step for 14-24 hr, or up to $72 \mathrm{hr}$ for larger or more dense samples. At ORAU, samples were oxidized for between 14 and $20 \mathrm{hr}$ depending on the fragility of each sample and the amount of material remaining after the acid and base washes. Each step was followed with thorough rinsing with ultrapure $\left(\mathrm{Milli}^{\mathrm{TM}}\right)$ water. The samples were then freeze-dried.

Table 1 Comparison of $\mathrm{ABA}$ and $\mathrm{ABOx}-\mathrm{SC}$ wet chemistry pretreatment procedures.

\begin{tabular}{ll}
\hline ABA & ABOx-SC \\
\hline $1 \mathrm{M} \mathrm{HCl}, 80^{\circ} \mathrm{C}, 20 \mathrm{~min}$ & $6 \mathrm{M} \mathrm{HCl}$, room temperature, $1 \mathrm{hr}$ \\
$0.2 \mathrm{M} \mathrm{NaOH}, 80^{\circ} \mathrm{C}, 20 \mathrm{~min}$ & $1 \mathrm{M} \mathrm{NaOH}$, room temperature, $30 \mathrm{~min}$ \\
$1 \mathrm{M} \mathrm{HCl}, 80^{\circ} \mathrm{C}, 1 \mathrm{hr}$ & $0.1 \mathrm{M} \mathrm{K} \mathrm{Cr}_{2} \mathrm{O}_{7}$ in $2 \mathrm{M} \mathrm{H}_{2} \mathrm{SO}_{4}, 60{ }^{\circ} \mathrm{C}, 14-20 \mathrm{hr}$ \\
\hline
\end{tabular}

The ABOx-SC samples were precombusted at $630^{\circ} \mathrm{C}$ for $2 \mathrm{hr}$ to remove any remaining organic contaminants. This combustion was carried out in the presence of copper oxide wire and quartz wool (which had both previously been baked out at $850{ }^{\circ} \mathrm{C}$ for $8 \mathrm{hr}$ to remove impurities) in a sealed evacuated quartz glass tube. 
The ABA and ABOx-SC samples were then combusted using a Europa Scientific ANCA-MS with a 20-20 IR mass spectrometer interfaced to a Roboprep CHN sample converter unit operating in continuous-flow mode with $\mathrm{He}$ carrier gas. The $\mathrm{CO}_{2}$ released was collected cryogenically and converted to graphite via reduction over an iron catalyst in an excess $\mathrm{H}_{2}$ atmosphere at $560{ }^{\circ} \mathrm{C}$ prior to accelerator mass spectrometry (AMS) ${ }^{14} \mathrm{C}$ measurement. The graphite targets analyzed at the ORAU are routinely $\sim 1.7 \mathrm{mg}$ but can be smaller than $1 \mathrm{mg}$, down to a minimum of $\sim 100-150 \mathrm{mg}$ in some experimental cases. We are working on the dating of very small graphites at present to expand the range of dateable materials.

The analysis of laboratory backgrounds, produced on a range of charcoal and wood standards known to date prior to $\sim 60 \mathrm{kyr} \mathrm{BP}$, effectively provides a measurement limit of $0.1 \mathrm{pMC}(\sim 55,000$ BP) for dating wood charcoal material. Conventional ages beyond this are recalculated and issued as "greater than" ages.

\section{RESULTS}

Of the 21 samples treated using the ABOx-SC pretreatment, 12 failed due to low or no yield. Previous work had indicated that due to the harshness of the $\mathrm{ABOx}-\mathrm{SC}$ treatment a minimum starting sample weight of at least $50 \mathrm{mg}$ (ideally $100 \mathrm{mg}$ ) of charcoal is required to yield enough material to date (compared with 10-20 mg or less for the ABA pretreatment), but despite this at least 1 sample from each of the sites and all of the samples from Grotte des Pigeons and Gorham's Cave failed. Interestingly, 7 of the samples that had previously been dated and the 2 samples from Grotte des Pigeons also failed the ABA pretreatment, although it should be noted that some of the original dates on material from Gorham's Cave and Taramsa Hill had previously undergone a less rigorous pretreatment, which did not include a base wash. It is possible that chemical changes arising from longterm storage of charcoals at ORAU might contribute to increasing fragility of the material.

The ${ }^{14} \mathrm{C}$ dates for the samples that did yield insoluble material after the $\mathrm{ABA}$ and $\mathrm{ABOx}-\mathrm{SC}$ pretreatments are given in Table 2. There is no difference in age between the 2 pretreatment methods for the samples from Kebara Cave or Taramsa Hill, which suggests that the ABA pretreatment is sufficient to remove any contaminants from the samples. Three of the 6 samples from Grotta di Fumane, however, yielded significantly older (up to $5 \mathrm{kyr}$ ) dates when treated with the ABOx-SC method. The other 3 samples yielded similar dates with both methods.

It is interesting to note that regardless of whether or not the 2 pretreatment methods result in different dates, the $\mathrm{ABOx}-\mathrm{SC}$ method generally yields material with a higher \% carbon content than the ABA method (Table 2).

\section{CASE STUDY: GROTTA DI FUMANE}

The Campanian Ignimbrite (CI) forms a crucial isochronous marker bed in the eastern Mediterranean, dating the arrival and dispersal of anatomically modern humans and the transition to the Upper Paleolithic in Europe. The $\mathrm{CI}$ has been ${ }^{40} \mathrm{Ar} /{ }^{39} \mathrm{Ar}$ dated to $\sim 40 \mathrm{kyr} \mathrm{BP}$ and is thought to coincide with the Laschamp Geomagnetic Excursion, which dates to 41-39 kyr BP on the GISP2 timescale (Giaccio et al. 2006). Pyle et al. (2006) have suggested that an age of $39.3 \mathrm{kyr}$ BP be adopted as the age of the Y5/CI, based on these ${ }^{40} \mathrm{Ar} /{ }^{39} \mathrm{Ar}$ data. Giaccio et al. (2006) compared ${ }^{14} \mathrm{C}$ ages from a marine core in the Tyrrhenian Sea, plus material from the Italian, Russian, and Bulgarian Paleolithic, above and below the CI. They found a wide variation in age range, which they attributed to variations in ${ }^{14} \mathrm{C}$ concentrations produced by the Laschamp Geomagnetic Excursion, at a far greater magnitude than previously realized. 
Table $2{ }^{14} \mathrm{C}$ ages of charcoal from the Grotta di Fumane, Kebara Cave, and Taramsa Cave. Treatment denotes the pretreatment method, $\mathrm{ABA}$ for acid-base-acid, and $\mathrm{ABOX}$ for $\mathrm{ABOx}-\mathrm{SC} . \% \mathrm{C}$ is the carbon content of the pretreated charcoal on combustion (prior to graphitization). $\delta^{13} \mathrm{C}$ values are expressed in \%owrt to VPDB with a measurement precision of $\pm 0.2-0.3 \%$.

\begin{tabular}{|c|c|c|c|c|c|c|}
\hline OxA\# & Site & Context & Treatment & ${ }^{14} \mathrm{C}$ age (BP) & $\% \mathrm{C}$ & $\delta^{13} \mathrm{C}(\% \circ)$ \\
\hline 11348 & Grotta di Fumane & Lyr D1d & $\mathrm{ABA}$ & $31,490 \pm 250$ & 55.4 & -23.4 \\
\hline 17571 & & & ABOX & $31,590 \pm 160$ & 78.6 & -22.3 \\
\hline 8051 & Grotta di Fumane & $\begin{array}{l}\text { Lyr D3ba, } \\
\text { h. } 15 \text {, sq. } 57\end{array}$ & $\mathrm{ABA}$ & $32,020 \pm 340$ & 62.2 & -24.8 \\
\hline 18200 & & & $\mathrm{ABA}$ & $32,600 \pm 190$ & 47.6 & -24.5 \\
\hline 17981 & & & ABOX & $33,890 \pm 220$ & 68.7 & -24.8 \\
\hline 11347 & Grotta di Fumane & $\begin{array}{l}\text { Lyr A2, sq. } \\
\text { 97d }\end{array}$ & $\mathrm{ABA}$ & $30,650 \pm 260$ & 58.5 & -25.2 \\
\hline 17569 & & & $\mathrm{ABOX}$ & $35,640 \pm 220$ & 80.6 & -22.5 \\
\hline 11360 & Grotta di Fumane & $\begin{array}{l}\text { Lyr A2, sq. } \\
107 i\end{array}$ & $\mathrm{ABA}$ & $31,830 \pm 260$ & 44.3 & -23.3 \\
\hline 17570 & & & ABOX & $35,180 \pm 220$ & 74.5 & -21.7 \\
\hline 6463 & Grotta di Fumane & $\begin{array}{l}\text { Lyr A5, sqs. } \\
85,86,95,96\end{array}$ & $\mathrm{ABA}$ & $33,700 \pm 600$ & 62.3 & -22.1 \\
\hline 18199 & & & $\mathrm{ABA}$ & $36,860 \pm 700$ & 60.7 & -21.2 \\
\hline 17980 & & & ABOX & $40,150 \pm 350$ & 74.4 & -21.1 \\
\hline 8022 & Grotta di Fumane & $\begin{array}{l}\text { Lyr A5+A6, } \\
\text { sq. } 90\end{array}$ & $\mathrm{ABA}$ & $38,800 \pm 750$ & 42.1 & -23.8 \\
\hline 8023 & & & $\mathrm{ABA}$ & $38,250 \pm 700$ & 66.3 & -24.2 \\
\hline 17567 & & & $\mathrm{ABA}$ & $39,500 \pm 330$ & 60.4 & -24.2 \\
\hline 17568 & & & $\mathrm{ABA}$ & $39,490 \pm 350$ & 57.8 & -24.5 \\
\hline 17566 & & & ABOX & $40,460 \pm 360$ & 62.1 & -24.4 \\
\hline 3977 & Kebara Cave & 4/Q15 III Bf & $\mathrm{ABA}$ & $>43,800$ & 47.1 & -26.2 \\
\hline 18425 & & & $\mathrm{ABA}$ & $41,200 \pm 450$ & 60.5 & -25.7 \\
\hline 18424 & & & ABOX & $40,350 \pm 400$ & 67.5 & -25.6 \\
\hline 3979 & Kebara Cave & 6/Q14d V & $\mathrm{ABA}$ & $>44,000$ & 45.3 & -25.5 \\
\hline 18427 & & & $\mathrm{ABA}$ & $47,300 \pm 800$ & 59.4 & -25.9 \\
\hline 18426 & & & ABOX & $46,250 \pm 700$ & 67.0 & -25.2 \\
\hline 5232 & Taramsa-2 & ME 94/18/6 & $\mathrm{ABA}$ & $43,600 \pm 3400^{a}$ & 60.0 & -27.3 \\
\hline 17378 & & & $\mathrm{ABA}$ & $43,650 \pm 550$ & 61.4 & -27.7 \\
\hline 17534 & & & ABOX & $43,100 \pm 500$ & 81.1 & -26.5 \\
\hline
\end{tabular}

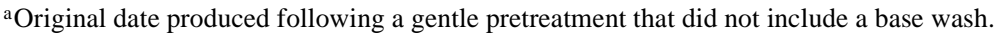

One of the Italian sites included in the study of Giaccio et al. (2006) was Grotta di Fumane, although tephra from the CI has yet to be found there. This site has previously produced a dated sequence for the Middle to Upper Paleolithic levels of $\sim 31-42 \mathrm{kyr}$ BP (Peresani et al. 2008). Of the 6 samples in this study which produced a date from the site using the ABOx-SC method, 3 produced substantial age differences of up to $5000 \mathrm{yr}$ older than the ABA dates, suggesting contamination of the samples which was not removed by traditional ${ }^{14} \mathrm{C}$ pretreatment procedures, rather than dramatic variations in ${ }^{14} \mathrm{C}$ concentrations during the Laschamp Excursion. These new dates show good agreement with ages of the Middle to Upper Paleolithic transition in the south of Italy based on the CI. Numerous samples from this site have been dated by 5 different laboratories (Peresani et al. 2008), but the $\mathrm{ABOx}-\mathrm{SC}$ dates in this study suggest that many of these dates are inaccurate. For example, 16 of the 21 determinations from level A2 (Figure 2) now appear to be too young for their context. Similarly, 3 of 4 dates from level A3 appear too young by at least $6000 \mathrm{yr}$. However, half of the ABOx- 


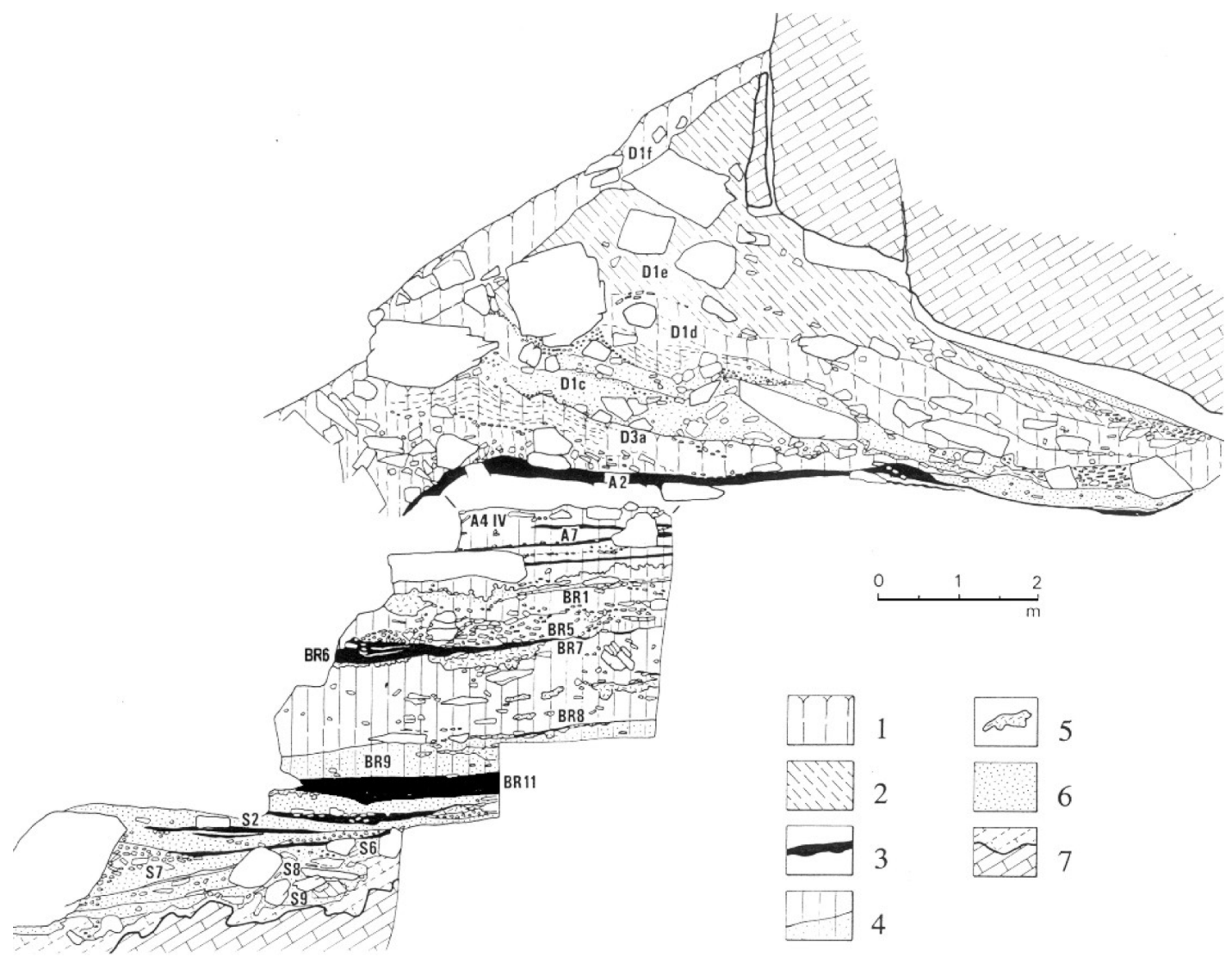

Figure 2 Stratigraphic sequence at the Grotta di Fumane. Level A2 is the Proto-Aurignacian level, D1 and D2 are Aurignacian, while below these, A4 and A3 are Uluzzian levels. A5 and A6 appear in a separate section of the excavation. Key: 1denotes rendzina, upper soil; 2-slope deposits with boulders; 3-living floors, with high concentrations of organic matter or charcoal; 4-loess and sandy loess; 5- $\mathrm{CaCO}_{3}$ cemented layers; 6-sandy deposits; 7-unweathered and weathered bedrock (modified from Cremaschi et al. 2005).

SC dates did not differ from the ABA ages, indicating that contamination is variable throughout the site. The re-interpretation of these results, and comparison with the proposals of Giaccio et al. (2006), are discussed in more detail by Higham et al. (2009b).

\section{CONCLUSIONS}

The ABOx-SC method of pretreatment for charcoal samples can sometimes result in significantly older ${ }^{14} \mathrm{C}$ dates than those obtained using $\mathrm{ABA}$ pretreatments on the same material. These new dates can dramatically change the interpretation of results from key Paleolithic sites and the comparison of different levels of single sites with others in the wider orbit, region, and continent. However, in many cases the $\mathrm{ABOx}-\mathrm{SC}$ and $\mathrm{ABA}$ pretreatments result in statistically identical dates, indicating that in these cases the ABA procedures are sufficient to remove environmental contamination from the samples. Such contamination appears to vary both within and between archaeological sites.

The ABOx-SC method is, however, particularly harsh and requires a relatively large amount (typically $>100 \mathrm{mg}$ ) of well-preserved charcoal to be able to yield sufficient material to date. Hence, the method cannot be applied to samples from some archaeological sites, although there is currently no 
easy way to predict the likelihood of samples surviving pretreatment beforehand. More work is needed in characterizing structurally the charcoal to be dated in order to understand the influences of chemical preparation methods. Such work is being undertaken by some research groups (e.g. Alon et al. 2002; Cohen-Ofri et al. 2006; Bird et al. 2008; Ascough et al. 2008) on different materials including archaeological charcoal and environmental black carbon of different ages and from different environments.

\section{ACKNOWLEDGMENTS}

This work was funded through a NERC/AHRC ORADS grant for ${ }^{14} \mathrm{C}$ dating. The authors wish to thank A Broglio and M Peresani (Grotta di Fumane), O Bar-Yosef (Kebara Cave), and P Vermeersch (Taramsa Hill) for kind permission to redate sample material. N Barton kindly donated newly excavated charcoal samples from Grotte des Pigeons for dating for this project.

\section{REFERENCES}

Alon D, Mintz G, Cohen I, Weiner S, Boaretto E. 2002. The use of Raman spectroscopy to monitor the removal of humic substances from charcoal. Radiocarbon 44(1):1-11.

Ascough PL, Bird MI, Brock F, Higham TFG, Meredith W, Snape CE, Vane CH. 2008. Hydropyrolysis as a new tool for radiocarbon pre-treatment and the quantification of black carbon. Quaternary Geochronology 4(2):140-7.

Barton RNE, Bouzouggar A, Bronk Ramsey C, Collcutt SN, Higham TFG, Humphrey LT, Parfitt S, Rhodes EJ, Schwenninger JL, Stringer CB, Turner E, Ward S. 2007. Abrupt climatic change and chronology of the Upper Palaeolithic in northern and eastern Morocco. In: Mellars P, Boyle K, Bar-Yosef O, Stringer C, editors. Rethinking the Human Revolution: New Behavioural \& Biological Perspectives on the Origins and Dispersal of Modern Humans. Cambridge: Research Monographs of the McDonald Institute. p 177-86.

Bar-Yosef O, Vandermeersch B, Arensburg B, BelferCohen A, Goldberg P, Laville H, Meignen L, Rak Y, Speth JD, Tchernov E, Tiller A-M, Weiner S. 1992. The excavations in Kebara Cave, Mt. Carmel. Current Anthropology 33(5):497-550.

Bar-Yosef O, Arnold M, Mercier N, Belfer-Cohen A, Goldberg P, Housley R, Laville H, Meignen L, Vogel JC, Vandermeersch B. 1996. The dating of the Upper Paleolithic layers in Kebara Cave, Mt Carmel. Journal of Archaeological Science 23(2):297-306.

Bird MI, Gröcke DR. 1997. Determination of the abundance and carbon isotope composition of elemental carbon in sediments. Geochimica et Cosmochimica Acta 61(16):3413-23.

Bird MI, Ayliffe LK, Fifield LK, Turney CSM, Cresswell RG, Barrows TT, David B. 1999. Radiocarbon dating of 'old' charcoal using a wet oxidation, stepped-combustion procedure. Radiocarbon 41(2):127-40.

Bird MI, Fifield LK, Santos GM, Beaumont PB, Zhou Y, di Tada ML, Hausladen PA. 2003. Radiocarbon dating from 40 to $60 \mathrm{ka} \mathrm{BP}$ at Border Cave, South Africa. Quaternary Science Reviews 22(8-9):943-7.
Bird MI, Ascough PL, Young IM, Wood CV, Scott AC. 2008. X-ray microtomographic imaging of charcoal. Journal of Archaeological Science 35(10):2698-706.

Broglio A, Gurioli F. 2004. Le comportement symbolique des premiers Hommes modernes: les données de la Grotte de Fumane (Pré-Alpes vénitiennes). In: Otte M, editor. La Spiritualité. Etudes et Recherches Archéologiques 106. Liége: Université de Liége. p 97102.

Broglio A, De Stefani M, Tagliacozzo A, Gurioli F, Facciolo A. 2006. Aurignacian dwelling structures, hunting strategies and seasonality in the Fumane Cave (Lessini Mountains). In: Vasil'ev SA, Popov VV, Anikovich MV, Praslov ND, Sinitsyn AA, Hoffecker JF, editors. Kostenki \& the Early Upper Paleolithic of Eurasia: General Trends, Local Developments. St. Petersburg: Nestor-Historia Publications. p 263-8.

Chappell J, Head J, Magee J. 1996. Beyond the radiocarbon limit in Australian archaeology and Quaternary research. Antiquity 70(269):543-52.

Cohen-Ofri I, Weiner L, Boaretto E, Mintz G, Weiner S. 2006. Modern and fossil charcoal: aspects of structure and diagenesis. Journal of Archaeological Science 33(3):428-39.

Cremaschi M, Ferraro F, Peresani M, Tagliacozzo A. 2005. Il sito: nuovi contributi sulla stratigrafia, la cronologia, le faune a macromammiferi e le industrie del paleolitico antico. In: Broglio A, Dalmeri G. (a cura di) Pitture paleolitiche nelle Prealpi Venete: Grotta di Fumane e Riparo Dalmeri. Memorie Museo Civico Storia Naturale di Verona 9:12-22.

Cuzange M-T, Delqué-Kolic E, Goszlar T, Grootes PM, Higham TFG, Kaltnecker E, Nadeau M-J, Oberlin C, Paterne M, van der Plicht J, Bronk Ramsey C, Valladas H, Clottes J, Geneste J-M. 2007. Radiocarbon intercomparison program for the Chauvet Cave. Radiocarbon 49(2):339-47.

Finlayson JC, Pachego FG, Rodríguez-Vidal J, Fa DA, Gutierrez López J-M, Santiago Pérez A, Finlayson G, Allue E, Preysler JB, Cáceres I, Carrión J, Fernández Jalvo Y, Gleed-Owen CP, Jimenez Espejo FJ, López P, 
Sáez JA, Riquelme Cantal, JA, Sánchex Marco A, Guzman FG, Brown K, Fuentes N, Valarino CA, Villalpando A, Stringer CB, Martinez Ruiz F, Sakamoto F. 2006. Late survival of Neanderthals at the southernmost extreme of Europe. Nature 443(7113):850-3.

Giaccio B, Hajdas I, Peresani M, Fedele FG, Isaia R. 2006. The Campanian Ignimbrite tephra and its relevance for the timing of the Middle to Upper Palaeolithic shift. In: Conard NJ, editor. When Neanderthals and Modern Humans Met. Tübingen: Kerns Verlag. p 343-75.

Higham TFG, Barton H, Turney CSM, Barker G, Bronk Ramsey C, Brock F. 2009a. Radiocarbon dating of charcoal from tropical sequences: results from the Niah Great Cave, Sarawak and their broader implications. Journal of Quaternary Science 24(2):189-97.

Higham TFG, Brock F, Peresani M, Broglio A, Wood R, Douka K. 2009b. Problems with radiocarbon dating the Middle to Upper Palaeolithic transition in Italy. Quaternary Science Reviews 28(13-14):1257-67.

Higham TFG, Bronk Ramsey C, Cheney HMC, Brock F, Douka K. 2009c. The radiocarbon chronology of Gorham's Cave. In: Barton RNE, Stringer C, Finlayson C, editors. Gibraltar Neanderthals in Context. A Report of the 1995-98 excavations at Gorham's and Vanguard Caves, Gibraltar. Oxford: Oxford University Committee for Archaeology (OUCA).

Mellars P. 2006. Archeology and the dispersal of modern humans in Europe: deconstructing the "Aurignacian." Evolutionary Anthropology 15(5):167-82.

Peresani M, Cremaschi M, Ferraro F, Falguères C, Bahain J-J, Gruppioni G, Sibilia E, Quarta G, Calcagnile L, Dolo J-M. 2008. Age of the final Middle Palaeolithic and Uluzzian levels at Fumane Cave, northern Italy, using ${ }^{14} \mathrm{C}, \mathrm{ESR},{ }^{234} \mathrm{U} /{ }^{230} \mathrm{Th}$ and thermoluminescence methods. Journal of Archaeological Science
35(11):2986-96.

Pettitt PB, Bailey RM. 2000. AMS radiocarbon and luminescence dating of Gorham's and Vanguard Caves, Gibraltar, and implications for the Middle to Upper Palaeolithic transition in Iberia. In: Stringer CB, Barton RNE, Finlayson JC, editors. Neanderthals on the Edge: Papers from a Conference Marking the 150th Anniversary of the Forbes' Quarry Discovery, Gibraltar. Oxford: Oxbow Books. p 155-62.

Pyle DM, Ricketts GD, Margari V, van Andel TH, Sinitsyn AA, Praslov ND, Lisitsyn S. 2006. Wide dispersal and deposition of distal tephra during the Pleistocene 'Campanian Ignimbrite/Y5' eruption, Italy. Quaternary Science Reviews 25(21-22):2713-28.

Santos GM, Bird MI, Fifield LK, Parenti F, Guidon N, Hausladen PA. 2003. A revised chronology of the lowest occupation layer of Pedra Furada Rock Shelter, Piauí, Brazil: the Pleistocene peopling of the Americas. Quaternary Science Reviews 22(21-22):2303-10.

Turney CSM, Bird MI, Fifield LK, Roberts RG, Smith M, Dortch CE, Grün R, Lawson E, Ayliffe LK, Miller GH, Dortch J, Cresswell RG. 2001. Early human occupation at Devil's Lair, southwestern Australia 50,000 years ago. Quaternary Research 55(1):3-13.

Vermeersch PM, Paulisson E, Stokes S, Charlier C, van Peer P, Stringer C, Lindsay W. 1998. A Middle Palaeolithic burial of a modern human at Taramsa Hill, Egypt. Antiquity 72(277):475-84.

Wild EM, Neugebauer-Maresch C, Einwögerer T, Stadler P, Steier P, Brock F. 2008. ${ }^{14} \mathrm{C}$ dating of the Upper Paleolithic site at Krems-Hundssteig in Lower Austria. Radiocarbon 50(1):1-10.

Zilhão J, Pettitt B. 2006. On the new dates for Gorham's Cave and the late survival of Iberian Neanderthals. $\mathrm{Be}$ fore Farming 3:1-9. 